\title{
Persepsi Guru Dalam Implementasi Holistik Integratif Pendidikan Anak Usia Dini Pada Kondisi New Normal
}

\author{
Yani $^{1}$, Mohammad Salehudin ${ }^{2}$, Sri Yatun ${ }^{3}$, Denok Lailatin Komariah ${ }^{4}$, Nur Eka Rizky Aminda \\ Pratiwi Hidayati $^{6}$, Nur Latifah ${ }^{7}$, Aisyah $^{8}$ \\ 1,2,3,4,5,Pascasarjana PIAUD, Institut Agama Islam Negeri Samarinda, ${ }^{1}$ KB. Belia Binuang \\ Kecamatan Sepaku PPU, ${ }^{6} \mathrm{~KB} / \mathrm{TK}$ Selyca Islamic School Samarinda, ${ }^{7} \mathrm{TK}$ Tunas Darma \\ Sangatta Utara. ${ }^{8}$ TK Alam Baiturrahman, Bontang. \\ Email: yanimadan123@gmail.com
}

\begin{abstract}
Abstrak
Pembelajaran tatap muka menjadi primadona pembelajaran dengan berbagai bentuk dan hasil belajar yang diharapkan, namun di masa new normal sebagai kelanjutan pandemi covid-19 pembelajaran online menjadi kebijakan pemerintah tidak terkecuali di lavel PAUD, tujuan penelitian ini untuk mengetahui persepsi guru dalam implementasi holistik integratif pendidikan anak usia dini pada kondisi new normal. Pendekatan penelitian kuantitatif survey pada 49 responden guru PAUD di Kabupaten Penajam Paser Utara, dibagikan dalam google form dengan 12 item pertanyaan penelitian yang dianalisis dengan desktiptif kuantitatif. Hasil penelitian bahwa persepsi guru dalam implementasi Holistik Integratif (HI) dengan hasil sangat baik, artinya implementasi HI dalam pandangan guru PAUD berjalan dengan sangat baik meliputi dua komponen HI, pertama implementasi HI dengan prinsip pembelajaran PAUD kedua implementasi kecerdasan anak. Saran untuk penelitian selanjutnya dikembangakan pada studi berbagai variabel yang meliputi layanan, lembaga PAUD, kebijakan pemerintah, aspek penilaian dan aspek perkembangan pengetahuan AUD.
\end{abstract}

Kata Kunci: Persepsi Guru; Implementasi Holistik Integratif, PAUD, New Normal

\begin{abstract}
Face-to-face learning is the prima donna of learning with various forms and expected learning outcomes, but in the new normal era as a continuation of the Covid-19 pandemic online learning has become a government policy, including at the PAUD level, the purpose of this study is to determine teacher perceptions in the holistic, integrative implementation of children's education. early age in new normal conditions. A quantitative survey research approach to 49 PAUD teacher respondents in Penajam Paser Utara District, distributed in google form with 12 research question items analyzed using quantitative descriptive. The results of the study show that teachers' perceptions in implementing Integrative Holistic (HI) are very good, meaning that the implementation of HI in the view of PAUD teachers is going very well including two HI components, first the implementation of HI with the principles of PAUD learning, the second the implementation of children's intelligence. Suggestions for further research are developed on the study of various variables which include services, PAUD institutions, government policies, aspects of assessment and aspects of development of AUD knowledge.
\end{abstract}

Keywords: Teacher Perception; Integrative Holistic Implementation, PAUD, New Normal.

\section{PENDAHULUAN}

Pendidikan dan pembelajaran telah berjalan sesuai dengan ketentuan pemerintah Republik Indonesia melalui Undang-undang sistem pendidikan nasional, pembelajaran dilaksanakan dalam tatap muka di kelas-kelas dan lingkungan lembaga PAUD, namun dalam kondisi pandemic covid-19 pembelajaran PAUD dirubah menjadi pembelajaran di rumah, siswa belajar di rumah serta para guru pun mengajar dari rumah, yang dikenal dengan

Persepsi Guru (Yani,Salehudin,Yatun,Komariah,Aminda,Hidayati, Latifah, 394

Aisyah) 
pembelajaran online atau daring menjadi dinamika pembelajaran di Indonesia saat ini (Mansyur, 2020) sesuai dengan kebijakan belajar dari rumah (BDR) oleh Kementerian Pendidikan RI. Belajar dari rumah terus berjalan memerlukan peran orang tua mendampingi siswa belajar (Kurniati et al., 2020), dampak covid membuat persiapan pembelajaran oleh berbagai pihak walaupun mereka menemukan berbagai kendala dalam pembelajaran (Syah, 2020), seperti halnya guru menggunakan media social sebagai e-learning akibat dampak covid19 (Salehudin, 2020a).

Kondisi New Normal merupakan kelanjutan dari dari dampak covid 19 di Indonesia, sebagai negara yang ikut terdampak penyebaran wabah penyakit mematikan akibat virus yang masuk ke pernapasan menjadi parasite yang menyerang kekuatan tubuh manusia, akhirnya dapat menimbulkan penyakit yang menyebabkan kematian bagi penderitanya. Asal usulnya dari sebuah provinsi dari negara China (Aylward, Bruce (WHO); Liang, 2020; Hageman, 2020) dan terus berkembang hampir ke seluruh dunia sampai bulan November 2020.

Kondisi new normal membuat pembelajaran harus terus berjalan (Kusmana, 2011), AUD merupakan sosok unik dan perlu penanganan ekstra sebagai generasi bangsa di masa depan Indonesia (Ulfah, 2019) AUD memiliki hubungan erat dengan peran orang tua dalam menerapkan pembelajaran dari rumah (Cahyati \& Kusumah, 2020) perlu sebuah analisis untuk tujuan pembelajaran holistic integrative (Yulianto et al., 2016). Anak adalah pribadi yang utuh (Data Statistik Penduduk Indonesia, 2019), anak AUD menjadi sosok yang perlu diperhatiakan dan ditanamkan aspek pengetahuan, keterampilan dan aspek perilaku atau sikap, menanamkan nilai karakter AUD (Sarinastitin, 2019), sehingga PAUD memiliki peran dalam pembentukan karakter anak (Maryatun, 2016).

New normal sebagai kondisi pasca pandemic yang berangsur-angsur menghilang, namun pembelajaran tetap dijalankan sebagai pembelajaran online, pembelajaran menggunakan perangkat elektronik dan jaringan internet, interaksi dilakasanakan dalam sebuah tatap muka online atau daring. Sehingga pembelajaran online ini menimbulkan tipikal beberapa kendala yang di alami para guru dalam mengajar (Agustin et al., 2020), kendala lainnya dalam pembelajaran online (Lina Handayani, 2020), sedangkan pembelajaran online memiliki kelebihan yang dapat menyampaikan materi pelajaran, proses pembelajaran hingga evaluasi dan asessmen pembelajaran. Pembelajaran online berjalan dengan baik dan walaupun impelementasinya dengan berbagai kendala terus dijalankan (Nurdin \& Anhusadar, 2020)

Sosok guru menjalankan tugas mulia sebagai pendidik dalam berbagai bentuk pembelajaran, berbagai model bisa dilakukan guru untuk mencapai tujuan belajar dan kualitas pendidikan itu sendiri, seperti model dongeng sebagai pembentuk karakter anak (Juanda, 2018) demikian pula dengan model outbound dapat dijadikan sarana belajar karakter AUD (Wahjoedi et al., 2017) serta berbagai strategi dapat dilakukan untuk mencapai proses pembelajaran AUD yang maksimal (Hewi \& Asnawati, 2021), dengan memperhatikan berbagai faktor-faktor yang menyebabkan berpengaruhnya pada perkembangan moral AUD (Fitri \& Na'imah, 2020).

Perlu implementasi yang menjadi sarana mewujudkan rangakaian pembelajaran yang memiliki muatan dan kualitas yang tepat dan terbaik bagi pelaksanaan Pendidikan AUD, wujud dari sebuah aplikasi pembelajaran holistic integrative (HI) yang dilaksanakan di lembaga PAUD pada saat new normal. Demikian pula dengan konsep dan aplikasi pembelajaran holistik integratif anak usia dini (Wahyuni, 2019) holistic integrative dalam implementasinya (Elyana, 2017) pelaksanaan pembelajaran holistic integratif (Hidayati, 2017), perlu seuah manajemen karakter AUD yang baik (Zahro et al., 2019).

Persepsi Guru (Yani,Salehudin,Yatun,Komariah,Aminda,Hidayati, Latifah, 395 Aisyah) 
Dalam pembelajaran new normal, perlu berbagai pihak meningkatkan perhatiannya pada berbagai unsur pendidikan, bisa berupa sarana dan fasilitas belajar sampai pada unsur materi dan bahan ajar serta penilaian belajar. Menurut Sutjiono (2005), perlu menggunakan dan memanfaatkan media pembelajaran. Menggunakan multimedia dengan teknologi (Salehudin, 2020c) tidak hanya media, justru faktor lain seperti literasi digital perlu digalakkan dalam pembelajaran dalam kondisi new normal (Fatmawati, 2019) literasi AUD merupakan sarana mengenalkan dan menempatkan arah bagaimana anak bijak dan tepat menggunakan media digital saat ini (Salehudin, 2020b).

Berbagai studi yang membahas tentang holistik integratif AUD dalam berbagai literatur telah dilakukan penelitian dan di kaji dalam berbagai aspek, berikut diantara kajian tersebut, seperti misalnya pada pelembagaan model pengembangan HI (Nursalim \& Raharja, 2019), berbicara pula tentang penerapan model evaluasi CIPP- yang cocok untuk mengevaluasi Program Layanan HI (Jaya \& Ndeot, 2018; Lina et al., 2019), termasuk bagaimana pelayanan Kebutuhan Dasar Anak (Hajati, 2018). Selanjutnya yang berhubungan dengan kurikulum dan pembelajaran HI bagi AUD; kurikulum holistik integratif berbasis permainan tradisional(Pramudyani et al., 2017), Kurikulum - dan implementasi self regulated learning (Elyana, 2017), Implementasi Pendidikan(Agustini, 2015), Pendekatan Cashflow Quadrant(Hijriyani \& Machali, 2017), Analisis Pembelajaran (Yulianto et al., 2016), evaluasi PAUD (Agus Jatmiko, Eti Hadiati, 2020), Evaluasi HI (Wulandari et al., 2018), Evaluasi Program Pengembangan(Akbar, 2018), serta Education system in an islamic (Fauzi et al., 2019). Pembelajaran saat new normal dapat menjadi solusi pembelajaran dengan kondisi yang baru dan merubah keadaan dan cara-cara belajar saat ini. Solusi yang dapat di ambil dan diterapkan dengan Implementasi HI AUD saat ini (Suarta \& Rahayu, 2018), Kondisi gambaran saat ini yang menjadi acuan untuk aktivitas AUD dengan berbagai metode belajar di rumah untuk mewujudkan HI AUD dapat melibatkan kerjasama orang tua dalam literasi digital di saat BDR hingga diperlukan kerjasama berbagai pihak agar implementasi berjalan lancar di tengah pandemic covid-19 dan era new normal.

Dari berbagai studi terdahulu dan banyaknya literatur yang membahas HI pada pembelajaran AUD telah dikemukakan di atas, namun belum ada yang mengemukakan persepsi guru dalam implementasi HI pada kondisi new normal. Menarik untuk diteliti, dalam pembahasan yang berbeda dan menjadi dasar penelitian pendahuluan dalam studi lebih lanjut tentang new normal setelah hilangnya pandemic covid 19 yang menyerang negara Indonesia, sehingga dirumuskan ke dalam tujuan penelitian ini adalah untuk mengetahui persepsi guru dalam implementasi HI pada kondisi new normal dengan pertanyaan kunci bagaimana persepsi guru dalam implementasi HI pada kondisi new normal. 


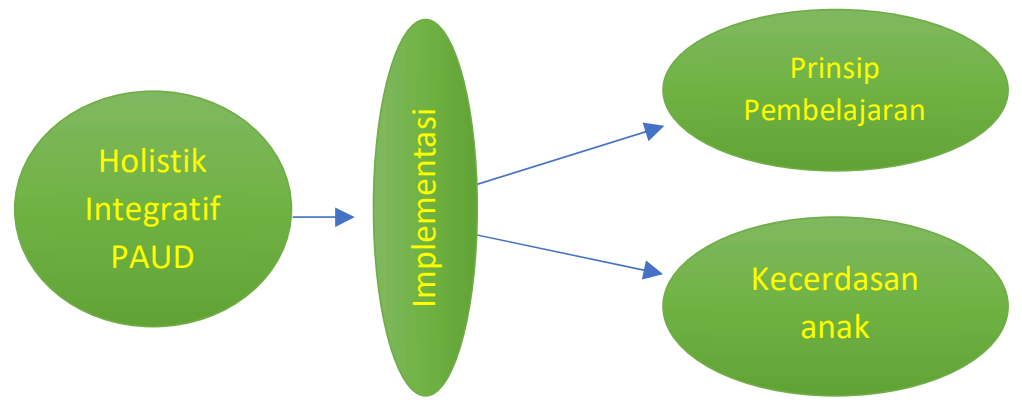

Gambar 1. Desain penelitian tentang persepsi guru dalam implementasi HI

\section{METODE PENELITIAN}

Penelitian ini menggunakan pendekatan kuantitatif yang dirancang dalam survey, data kuantitatif diperlukan dalam bentuk persentase, ditayangkan dalam bentuk deskriptif kuantitatif tentang persepsi guru dalam implementasi HI (Creswell, 2012; Sugiono, 2010). Responden ditentukan dengan random menggunakan purposive sampling pada guru PAUD yang berdomisili di Kabupaten PPU khsusunya kecamatan Sepaku dan Penajam, terdapat 49 orang responden yang memberikan jawaban melalui fasilitas google form yang di sebarkan melalui jaringan WhatsappGroup guru PAUD.

Intrumen disusun berdasarkan adaptasi berbagai teori yang memiliki kesesuaian dengan permasalahan penelitian dengan dua sub indicator dan menjadi 12 item pertanyaan penelitian yang diuraikan sebagai berikut: Holistik integratif yang berhubungan dengan prinsip Pembelajaran PAUD yaitu Berpusat pada anak;Berorientasi pada kebutuhan anak; Kegiatan belajar dilakukan melalui bermain; Merangsang munculnya kreativitas dan inovatif; Menyediakan lingkungan yang mendukung proses belajar; Mengembangkan kecakapan hidup anak

Sedangkan Kecerdasan anak diantaranya adalah: Kepekaan anak terhadap perasaan, kebutuhan, dan peristiwa yang dialami teman sebayanya; Kemampuan anak mengorganisasi teman-teman sebayanya; Kemampuan anak memotivasi dan mendorong orang lain untuk bertindak;Sikap yang menyenangkan, senang menjalin komunikasi, mau menerima teman baru, dan mudah berinteraksi di lingkungan baru; Kecenderungan anak untuk bekerja sama dengan orang lain, saling membantu, berbagi, dan mau mengalah; Kemampuan untuk menyelesaikan masalah yang terjadi di antara teman sebayanya, menyelaraskan perasaan teman-teman yang bertikai, dan kemampuan memberikan usulan-usulan perdamaian. Analisis data menggunakan deskriptif kuantitatif pada hasil penelitian dengan mengemukakan nilai-nilai persentase data.

\section{HASIL DAN PEMBAHASAN}

Hasil penelitian yang berhubungan dengan HI dengan prinsip pembelajaran PAUD meliputi Berpusat pada anak; Berorientasi pada kebutuhan anak; Kegiatan belajar dilakukan melalui bermain; Merangsang munculnya kreativitas dan inovatif; Menyediakan lingkungan yang mendukung proses belajar; Mengembangkan kecakapan hidup anak. 
Tabel 1. Hasil jawaban responden

\begin{tabular}{|c|c|c|c|c|}
\hline No & Item implementasi HI & $\mathbf{Y a}$ & Tidak & Mungkin \\
\hline A & $\begin{array}{l}\text { Holistik integratif yang berhubungan dengan } \\
\text { prinsip Pembelajaran PAUD: }\end{array}$ & & & \\
\hline 1 & Berpusat pada anak & $100 \%$ & & \\
\hline 2 & Berorientasi pada kebutuhan anak & $100 \%$ & & \\
\hline 3 & Kegiatan belajar dilakukan melalui bermain & $95,9 \%$ & & \\
\hline 4 & Merangsang munculnya kreativitas dan inovatif & $93,9 \%$ & $6,1 \%$ & \\
\hline 5 & $\begin{array}{l}\text { Menyediakan lingkungan yang mendukung proses } \\
\text { belajar }\end{array}$ & $98 \%$ & $2 \%$ & \\
\hline 6 & Mengembangkan kecakapan hidup anak & $98 \%$ & $2 \%$ & \\
\hline $\mathrm{B}$ & $\begin{array}{l}\text { Holistik integratif yang berhubungan dengan } \\
\text { Kecerdasan anak: }\end{array}$ & & & \\
\hline 7 & $\begin{array}{l}\text { Kepekaan anak terhadap perasaan, kebutuhan, dan } \\
\text { peristiwa yang dialami teman sebayanya }\end{array}$ & $85,7 \%$ & $14,3 \%$ & \\
\hline 8 & $\begin{array}{l}\text { Kemampuan anak mengorganisasi teman-teman } \\
\text { sebayanya }\end{array}$ & $85,7 \%$ & $14,3 \%$ & \\
\hline 9 & $\begin{array}{l}\text { Kemampuan anak memotivasi dan mendorong } \\
\text { orang lain untuk bertindak }\end{array}$ & $83,7 \%$ & $16,3 \%$ & \\
\hline 10 & $\begin{array}{l}\text { Sikap yang menyenangkan, senang menjalin } \\
\text { komunikasi, mau menerima teman baru, dan } \\
\text { mudah berinteraksi di lingkungan baru }\end{array}$ & $95,9 \%$ & $4,1 \%$ & \\
\hline 11 & $\begin{array}{l}\text { Kecenderungan anak untuk bekerja sama dengan } \\
\text { orang lain, saling membantu, berbagi, dan mau } \\
\text { mengalah }\end{array}$ & $93,9 \%$ & $6,1 \%$ & \\
\hline 12 & $\begin{array}{l}\text { Kemampuan untuk menyelesaikan masalah yang } \\
\text { terjadi di antara teman sebayanya }\end{array}$ & $79,6 \%$ & $18,4 \%$ & $2 \%$ \\
\hline
\end{tabular}

Persepsi implementasi HI dalam hal ini memiliki nilai 93\%-98\% yang berarti sangat tepat, guru mampu menyampaikan materi dan pembelajaran HI dengan benar dan tepat, serta terus dilaksanakan walaupun masa dampak covid-19 sampai new era. Dapat di lihat pada gambar berikut: 


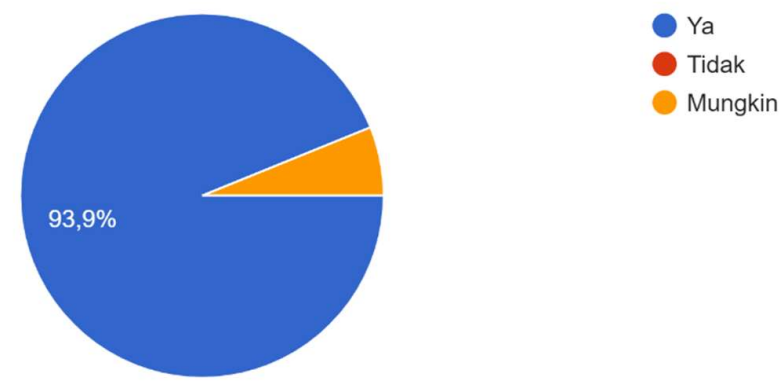

Gambar 1: Hasil implementasi HI merangsang munculnya kreativitas dan inovatif

Sedangkan nilai implementasi pada HI mengembangkan kecakapan hidup anak dapat dilihat pada gambar:
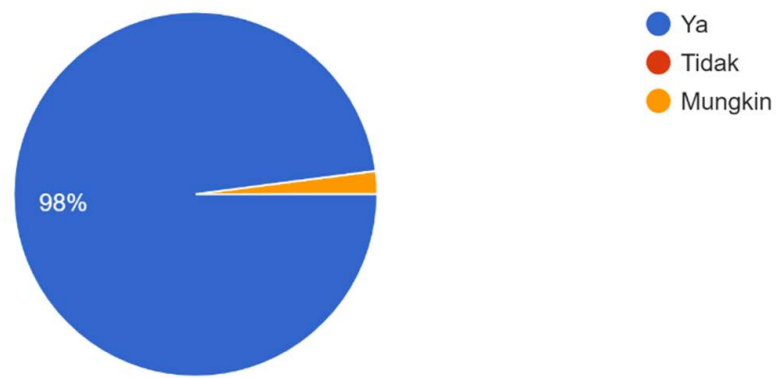

Gambar 2: Hasil implementasi HI mengembangkan kecakapan hidup anak

Untuk hasil penelitian implementasi HI terhadap kecerdasan anak, Hasil implementasi HI terhadap kepekaan anak terhadap perasaan, kebutuhan, dan peristiwa yang dialami teman sebayanya dan mengembangkan kecakapan hidup anak memiliki hasil sebagai berikut:

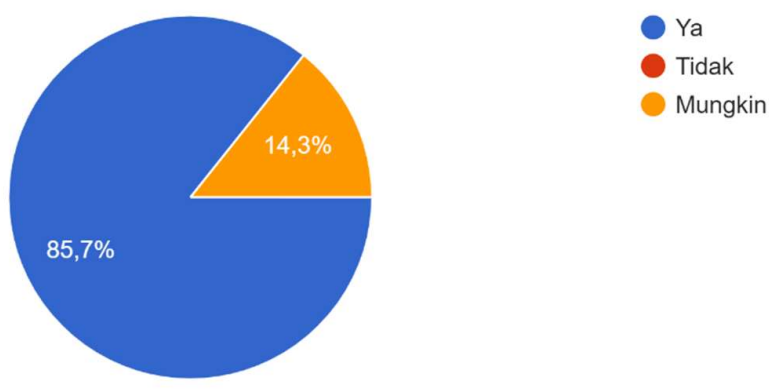

Gambar 3: Hasil implementasi HI mengembangkan kecakapan hidup anak

Untuk implementasi HI pada kemampuan anak memotivasi dan mendorong orang lain untuk bertindak, dalam gambar berikut: 


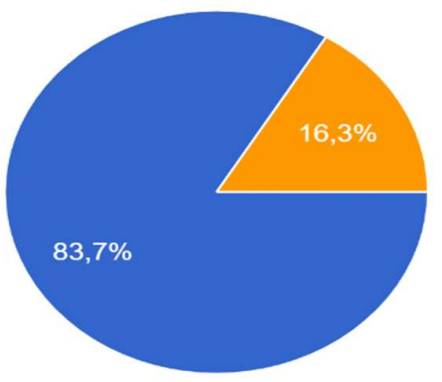

Gambar 4: Hasil implementasi HI kemampuan anak memotivasi dan mendorong orang lain

Demikian pula dengan kemampuan untuk menyelesaikan masalah yang terjadi di antara teman sebayanya.
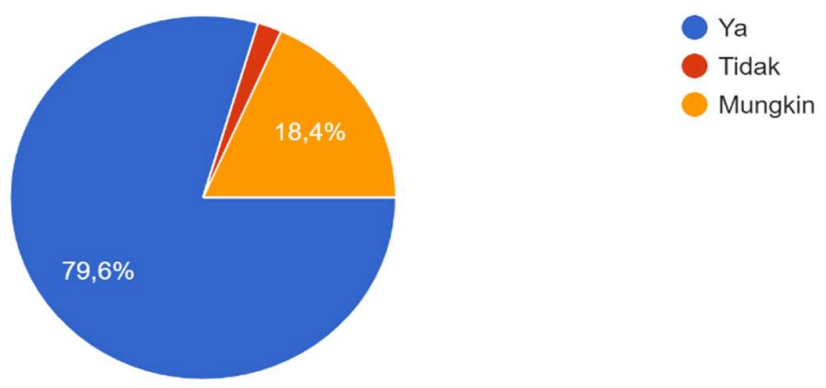

Gambar 5: Hasil implementasi HI Kemampuan untuk menyelesaikan masalah yang terjadi di antara teman sebayanya

Implementasi HI yang berhubungan dengan prinsip pembelajaran dan kecerdasan anak, bahwa pembelajaran dalam bentuk dan konsep apapun harus terus berjalan, maka pembelajaran online sebagai sarana belajar harus dijadikan wadah mengimplementasikan HI, tetap gunakan berbagai media computer dan pembelajaran online (Sung \& Mayer, 2013), bagaimana cara mengahadapi tantangan pembelajaran online (Dhawan, 2020), gunakan model pembelajaran yang tepat seperti menggunakan blended learning yang mengatur interaksi online dan offline (Wardani et al., 2018).

Prestasi akademik dan kecerdasan anak karena menurut Jumiatin et al., (2020) penerapan implementasi HI dalam meningkatkan kecerdasan interpersonal dan melalui multiple intelegensi. Kecerdasan intelektual, emosional dan spritual (Agustian, 2005), menumbuhkan kecerdasan anak dengan ayat-ayat al qur'an yang menghafal pada juz tertentu (Ana, Sri Saparahayuningsih, Indrawati, 2020), karakter melalui agama (Elfan Fanhas \& Gina Nurazizah, 2017) Pendidikan karakter pada disabiltas juga dapat dilakukan (Juherna et al., 2020) dan karakter dalam pandangan ajaran Islam (Inawati, 2017).

Persepsi Guru (Yani,Salehudin,Yatun,Komariah,Aminda,Hidayati, Latifah, 400 
Pembelajaran online untuk menyelesaikan berbagai proses pembelajaran menurut Lestari et al., (2019) berberapa tantangan yang harus dihadapi dalam pembelajaran menggunakan online atau menggunakan handphone seperti banyak budaya belajar yang terjadi masih relatif rendah; semata-mata mengerjakan tugas yang diberikan oleh dosen dengan membaca buku; pembelajaran serius dilakukan menjelang hari ujian; jarang membaca materi perkuliahan yang telah dipelajari sehingga pada saat perkuliahan berlangsung pertanyaan yang diajukan sangat dangkal. Menggunakan pembelajaran online untuk meningkatkan kepekaan social (Setyosari, 2009), termasuk aspek social disamping aspek lainnya dalam pembelajaran online (Tantri, 2018). Kozma dalam (Davis, n.d. h.3) berpendapat bahwa atribut tertentu dari komputer diperlukan untuk membawa model dan simulasi kehidupan nyata kepada siswa yang selanjutnya media mempengaruhi pembelajaran. Lihat gambar interaksi media dan pembelajaran online

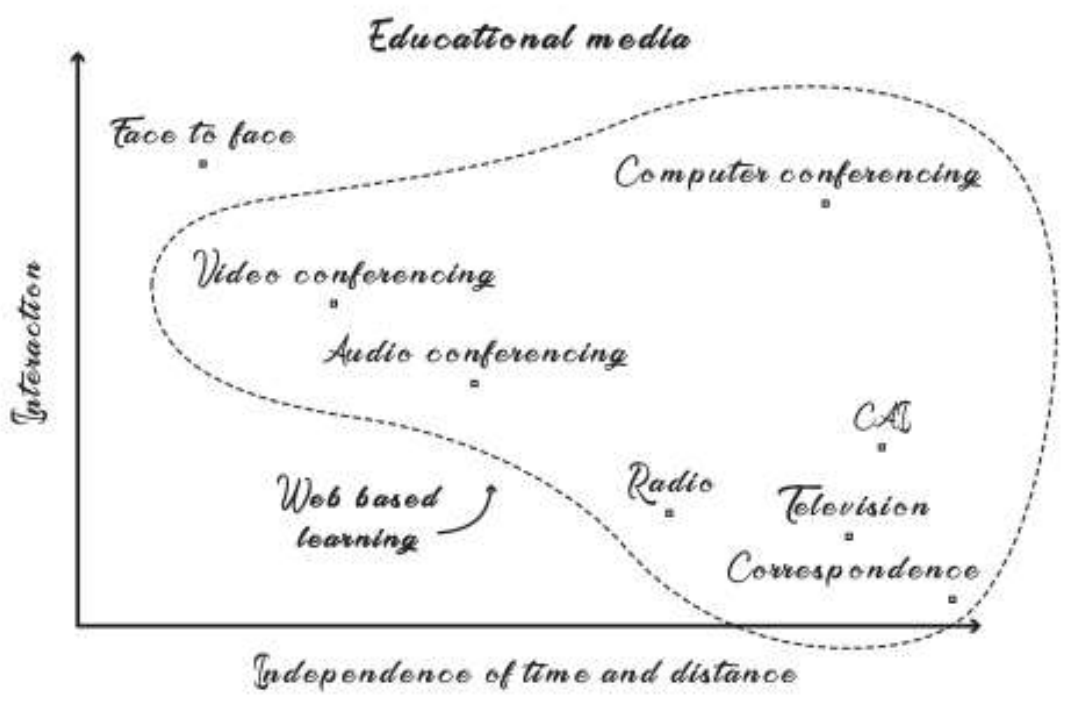

Gambar 7. Interaksi belajar menggunakan internet dan web

Dengan demikian, kapasitas internet untuk mendukung pembelajaran online secara umum biasanya merupakan domain yang terlalu besar untuk diskusi yang bermakna sampai seseorang menentukan modalitas interaksi tertentu yang digunakan. Pembelajaran online dengan berbagai learning managemen system (LMS) seperti pembelajaran online dengan scoology (Misbah et al., 2018) berbasis google classroom (Abazi-Bexheti et al., 2018).

HI diimplementasikan dalam dukungan berbagai model pembelajaran (Nursalim \& Raharja, 2019; Suarta \& Rahayu, 2018; Tantri Wahyuni, 2015), kemandirian belajar anak dalam pembelajaran online di era pandemic (Yuliati \& Saputra, 2020). Demikian pula dengan pemanfaatan berbagai teknologi informasi dalam pembelajaran jarak jauh (Pakpahan \& Fitriani, 2020). 


\section{KESIMPULAN}

Berdasarkan hasil penelitian persepsi guru dalam implementasi HI pada pembelajaran online kondisi new normal, meliputi implementasi HI berbasis prinsip pembelajaran PAUD dan kecerdasan anak. HI dengan prinsip pembelajaran PAUD meliputi Berpusat pada anak; Berorientasi pada kebutuhan anak; Kegiatan belajar dilakukan melalui bermain; Merangsang munculnya kreativitas dan inovatif; Menyediakan lingkungan yang mendukung proses belajar; Mengembangkan kecakapan hidup anak dan HI dengan implementasi kecerdasan anak; meliputi kepekaan anak terhadap perasaan, kebutuhan, Kemampuan anak mengorganisasi teman-teman sebayanya, kemampuan anak memotivasi dan mendorong orang lain untuk bertindak, sikap yang menyenangkan, senang menjalin komunikasi, mau menerima teman baru, dan mudah berinteraksi di lingkungan baru, kecenderungan anak untuk bekerja sama dengan orang lain, saling membantu, berbagi, dan mau mengalah dan kemampuan untuk menyelesaikan masalah yang terjadi di antara teman sebayanya.

Secara umum dapat disimpulkan bahwa persepsi guru dalam implementasi HI dengan hasil sangat baik, artinya implementasi HI dirasakan guru PAUD berjalan dengan sangat baik meliputi dua komponen HI, pertama implementasi HI dengan prinsip pembelajaran PAUD kedua implementasi kecerdasan anak. Saran untuk penelitian selanjutnya dikembangakan pada studi berbagai variabel yang meliputi layanan, lembaga PAUD, kebijakan pemerintah, aspek penilaian dan aspek perkembangan pengetahuan AUD.

\section{DAFTAR PUSTAKA}

Abazi-Bexheti, L., Kadriu, A., Apostolova-Trpkovska, M., Jajaga, E., \& Abazi-Alili, H. (2018). LMS Solution: Evidence of Google Classroom Usage in Higher Education. Business Systems Research, 9(1), 31-43. https://doi.org/10.2478/bsrj-2018-0003

Agus Jatmiko, Eti Hadiati, M. O. (2020). Penerapan Evaluasi Pembelajaran Anak Usia Dini. Al Athfaal: Jurnal Ilmiah Pendidikan Anak Usia Dini, 3(1), 83-97. http://ejournal.radenintan.ac.id/index.php/al-athfaal

Agustian, A. G. (2005). Rahasia Sukses Membangun Kecerdasan Emosi dan Spritual, ESQ; Emotional Spritual Quotiont (New Editio). Penerbit Arga.

Agustin, M., Puspita, R. D., Nurinten, D., \& Nafiqoh, H. (2020). Tipikal Kendala Guru PAUD dalam Mengajar pada Masa Pandemi Covid 19 dan Implikasinya. Jurnal Obsesi : Jurnal Pendidikan Anak Usia Dini, 5(1), 334. https://doi.org/10.31004/obsesi.v5i1.598

Agustini, S. (2015). Implementasi Pendidikan Holistik Integratif Pada Anak Usia Dini (Studi di PAUD Aisyiyah Bustanul Athfal Metro, Wahdatul Ummah, Al Ishlah Kota Metro). STAIN Jurai Siwo Metro.

Akbar, R. A. (2018). Evaluasi Program Pengembangan Anak Usia Dini Holistik Integratif Pada Satuan Paud. AWLADY: Jurnal Pendidikan Anak, 4(2), 137. https://doi.org/10.24235/awlady.v4i2.2703

Ana, Sri Saparahayuningsih, Indrawati, D. (2020). Studi Kasus Anak Hafal Al-Qur'an Juz 30 di PAUD IT Generasi Rabbani Kota Bengkulu. Jurnal Ilmiah Potensia, 5(1), 45-55.

Aylward, Bruce (WHO); Liang, W. (PRC). (2020). Report of the WHO-China Joint Mission on Coronavirus Disease 2019 (COVID-19). 2019(February), 16-24.

Persepsi Guru (Yani,Salehudin,Yatun,Komariah,Aminda,Hidayati, Latifah, 402 
Cahyati, N., \& Kusumah, R. (2020). Peran Orang Tua Dalam Menerapkan Pembelajaran Di Rumah Saat Pandemi Covid 19. Jurnal Golden Age, Universitas Hamzanwadi, 04(1), 152 159.

Creswell, J. W. (2012). Educational Research; Planning, Conduction and Evaluating Quantitative and Qualitative Research. Pearson Education. Inc.

Data Statistik Penduduk Indonesia. (2019). Jumlah Penduduk Indonesia 2019 Mencapai 267 Juta Jiwa. Dkatadata.Co.Id, 1. https://databoks.katadata.co.id/datapublish/2019/01/04/jumlah-penduduk-indonesia2019-mencapai-267-juta-jiwa

Davis, A. (n.d.). Theory and Practice of Online Learning (T. Anderson \& F. Elloumi (eds.)). Athabasca University.

Dhawan, S. (2020). Online Learning: A Panacea in the Time of COVID-19 Crisis. Journal of Educational Technology Systems, 49(1), 5-22. https://doi.org/10.1177/0047239520934018

Elfan Fanhas, F. K., \& Gina Nurazizah, M. (2017). Pendidikan Karakter Untuk Anak Usia Dini Menurut Q.S. Lukman : 13 - 19. PEDAGOGI: Jurnal Anak Usia Dini Dan Pendidikan Anak Usia Dini Volume, 3(3a), 42-51. http://103.114.35.30/index.php/Pedagogi/article/view/1032

Elyana, L. (2017). Kurikulum holistik integratif anak usia dini dalam implementasi self regulated learning. Prosiding HIPKIN Jateng, 1(1), 1-7.

Fatmawati, N. I. (2019). Literasi Digital, Mendidik Anak Di Era Digital Bagi Orang Tua Milenial. MADANI: Jurnal Politik Dan Sosial Kemasyarakatan, 11(9), 119-138. https://doi.org/10.1017/CBO9781107415324.004

Fauzi, Supa'at, \& Novikasari, I. (2019). Holistic-integrative education system in an islamic kindergarten. Qudus International Journal of Islamic Studies, 7(2), 399-414. https://doi.org/10.21043/qijis.v7i2.6449

Fitri, M., \& Na'imah. (2020). Faktor Yang Mempengaruhi Perkembangan Moral Pada Anak Usia Dini. Al Athfaal: Jurnal Ilmiah Pendidikan Anak Usia Dini, 3(1), 1-15. https://www.kompasiana.com/www.kompasiana.comamqurrota_55208248a3331131474 6ce79/faktor-yang-mempengaruhi-perkembangan-bahasa-pada-anak

Hageman, J. R. (2020). The Coronavirus Disease 2019 (COVID-19). Pediatric Annals, 49(3), e99-e100. https://doi.org/10.3928/19382359-20200219-01

Hajati, K. (2018). Pelaksanaan Pendidikan Holistik-Integratif dalam Pelayanan Kebutuhan Dasar Anak Usia Dini di Kabupaten Mamuju Sulawesi-Barat. Indonesian Journal of Educational Science (IJES), 1(1), 17-24. https://doi.org/10.31605/ijes.v1i1.133

Hewi, L., \& Asnawati, L. (2021). Strategi Pendidik Anak Usia Dini Era Covid-19 dalam Menumbuhkan Kemampuan Berfikir Logis. Jurnal Obsesi : Jurnal Pendidikan Anak Usia Dini, 5(1), 158-167. https://doi.org/10.31004/obsesi.v5i1.530

Hidayati, U. (2017). Pendidikan Holistik Integratif Di Raudlatul Athfal (Ra). EDUKASI: Jurnal Penelitian Pendidikan Agama Dan Keagamaan, 15(2), 241-262. https://doi.org/10.32729/edukasi.v15i2.451

Persepsi Guru (Yani,Salehudin,Yatun,Komariah,Aminda,Hidayati, Latifah, 403 Aisyah) 
Hijriyani, Y. S., \& Machali, I. (2017). Pembelajaran Holistik - Integratif Anak Usia Dini dengan Pendekatan Cashflow Quadrant di RA Al Muttaqin Tasikmalaya. Al-Athfal: Jurnal Pendidikan Anak, 3(2), 119. https://doi.org/10.14421/al-athfal.2017.32-02

Inawati, A. (2017). Strategi Pengembangan Moral dan Nilai Agama Untuk Anak Usia Dini. Jurnal Pendidikan Anak, 3(1), 51-64.

Jaya, P. R. P., \& Ndeot, F. (2018). Penerapan Model Evaluasi CIPP Dalam Mengevaluasi Program Layanan PAUD Holistik Integratif. PERNIK Jurnal PAUD, 1(1), 10-25.

Juanda. (2018). Revitalisasi Nilai Dalam Dongeng Sebagai Wahana Pembentukan Karakter Anak Usia Dini. Jurnal Pustaka Budaya, 5(2), 11-18. https://doi.org/10.19109/ra.v1i2.2684

Juherna, E., Purwanti, E., Melawati, \& Utami, Y. S. (2020). Implementasi Pendidikan Karakter Pada Disabilitas Anak Tunarungu. Jurnal Golden Age, Universitas Hamzanwadi, 04(1), $12-19$.

Jumiatin, D., Windarsih, C. A., \& Sumitra, A. (2020). Penerapan Metode Holistik Integratif Dalam Meningkatkan Kecerdasan Interpersonal. Tunas Siliwangi : Jurnal Program Studi Pendidikan Anak Usia Dini STKIP Siliwangi, Bandung, 6(2), 1-8.

Kurniati, E., Nur Alfaeni, D. K., \& Andriani, F. (2020). Analisis Peran Orang Tua dalam Mendampingi Anak di Masa Pandemi Covid-19. Jurnal Obsesi : Jurnal Pendidikan Anak Usia Dini, 5(1), 241. https://doi.org/10.31004/obsesi.v5i1.541

Kusmana, A. (2011). E-Learning Dalam Pembelajaran. Lentera Pendidikan, 14(1), 35-51.

Lestari, I., Maksum, A., \& Kustandi, C. (2019). Mobile Learning Design Models for State University of Jakarta, Indonesia. International Journal of Interactive Mobile Technologies (IJIM), 13(9), 152-171. https://doi.org/https://doi.org/10.3991/ijim.v13i09.10987

Lina Handayani. (2020). Keuntungan , Kendala dan Solusi Pembelajaran Online Selama Pandemi Covid-19: Studi Ekploratif di SMPN 3 Bae Kudus Lina Handayani. Journal Industrial Engineering \& Management Research (Jiemar), 1(2), 15-23.

Lina, L., Suryana, D., \& Nurhafizah, N. (2019). Penerapan Model Evaluasi CIPP dalam Mengevaluasi Program Layanan PAUD Holistik Integratif. Jurnal Obsesi: Jurnal Pendidikan Anak Usia Dini, 3(2), 346. https://doi.org/10.31004/obsesi.v3i2.200

Mansyur, A. R. (2020). Dampak COVID-19 Terhadap Dinamika Pembelajaran Di Indonesia. Education and Learning Journal, 1(2), 113. https://doi.org/10.33096/eljour.v1i2.55

Maryatun, I. B. (2016). Peran Pendidik Paud Dalam Membangun Karakter Anak. Jurnal Pendidikan Anak, 5(1), 747-752. https://doi.org/10.21831/jpa.v5i1.12370

Misbah, M., Pratama, W. A., Hartini, S., \& Dewantara, D. (2018). Pengembangan E-Learning Berbasis Schoology pada Materi Impuls dan Momentum untuk Melatihkan Literasi Digital. PSEJ (Pancasakti Science Education Journal), 3(2), 109. https://doi.org/10.24905/psej.v3i2.1067

Nurdin, N., \& Anhusadar, L. (2020). Efektivitas Pembelajaran Online Pendidik PAUD di Tengah Pandemi Covid 19. Jurnal Obsesi : Jurnal Pendidikan Anak Usia Dini, 5(1), 686697. https://doi.org/10.31004/obsesi.v5i1.699

Persepsi Guru (Yani,Salehudin,Yatun,Komariah,Aminda,Hidayati, Latifah, 404 Aisyah) 
Nursalim, \& Raharja, S. P. (2019). Memperkuat Pelembagaan Model Pengembangan Anak Usia Dini Holistik Integratif (PAUD HI) Di Kabupaten Sorong Dan Kabupaten Raja Ampat. Jurnal ABDIMASA Pengabdian Masyarakat, 2(2), 18-28.

Pakpahan, R., \& Fitriani, Y. (2020). Analisa Pemanfaatan Teknologi Informasi Dalam Pembelajaran Jarak Jauh Di Tengah Pandemi Virus Corona Covid-19. JISAMAR (Journal of Information System, Applied, Management, Accounting and Researh), 4(2), 30-36.

Pramudyani, A. V. R., Kurniawan, M. R., Rasyid, H., \& Sujarwo. (2017). Kurikulum Holistik Integratif Berbasis Permainan Tradisional Pada PAUD Di Yogyakarta. Jurnal Penelitian Ilmu Pendidikan, 10(2), 86-96.

Salehudin, M. (2020a). Dampak Covid-19: Guru Mengadopsi Media Sosial Sebagai ELearning Pada Pembelajaran Jarak Jauh. Jurnal MUDARRISUNA, 10(1), 1-16.

Salehudin, M. (2020b). Literasi Digital Media Sosial Youtube Anak Usia Dini. Jurnal Ilmiah Potensia, 5(2), 106-115.

Salehudin, M. (2020c). Penggunaan Multimedia Berbasis Teknologi Bagi Pendidikan Profesi Guru (PPG): Analisis User Experience (UX). Al-Tadzkiyyah: Jurnal Pendidikan Islam, 11(1), 93-109.

Sarinastitin, E. (2019). Pembentukan Karakter Anak Usia Dini. Jurnal Lonto Leok Pendidikan Anak Usia Dini, 2(1), 95-102.

Setyosari, P. (2009). Pembelajaran Kolaborasi, Landasan Untuk Mengembangkan Keterampilan Sosial, Rasa Saling Menghargai dan Tanggung Jawab. In Pidato Pengukuhan Guru Besar dalam Bidang Ilmu Teknologi Pembelajaran. Fakultas Ilmu Pendidikan Universitas Negeri Malang.

Suarta, I. N., \& Rahayu, D. I. (2018). Model Pembelajaran Holistik Integratif di PAUD Untuk Mengembangkan Potensi Dasar Anak Usia Dini. Jurnal Ilmiah Profesi Pendidikan, 3(1), 37. https://doi.org/10.29303/jipp.Vol3.Iss 1.44

Sugiono. (2010). Metode Penelitian Pendidikan; Pendekatan Kuantitatif, Kualitatif dan R\&D (cetakan ke). Alfabeta, CV.

Sung, E., \& Mayer, R. E. (2013). Computers in Human Behavior Online multimedia learning with mobile devices and desktop computers : An experimental test of Clark's methodsnot-media hypothesis. Computers in Human Behavior Journal, 29, 639-647.

Sutjiono, T. W. A. (2005). Pendayagunaan Media Pembelajaran. Jurnal Pendidikan Penabur (JPP), No.4/IV, 76-84.

Syah, R. H. (2020). Dampak Covid-19 pada Pendidikan di Indonesia: Sekolah, Keterampilan, dan Proses Pembelajaran. SALAM: Jurnal Sosial Dan Budaya Syar-I, 7(5). https://doi.org/10.15408/sjsbs.v7i5.15314

Tantri, N. R. (2018). Kehadiran Sosial Dalam Pembelajaran Daring Berdasarkan Sudut Pandang Pembelajar Pendidikan Terbuka Dan Jarak Jauh. Jurnal Pendidikan Terbuka Dan Jarak Jauh, 19(1), 19-30. https://doi.org/10.33830/ptjj.v19i1.310.2018

Tantri Wahyuni. (2015). Model Pembelajaran Experiential Kolb Dengan Visualisasi Virtual Untuk Meningkatkan Pemahaman Konsep Pada Mata Kuliah Fisika Dasar Listrik (Studi Kasus: Teknik Informatika Universitas Majalengka). Seminar Nasional Informatika 2015

Persepsi Guru (Yani,Salehudin,Yatun,Komariah,Aminda,Hidayati, Latifah, 405 
(SemnasIF 2015), 2015(November), 292-307. https://doi.org/ISSN: 1979-2328 2.

Ulfah, M. (2019). Pendekatan Holistik Integratif Berbasis Penguatan Keluarga pada Pendidikan Anak Usia Dini Full Day. Jurnal Obsesi : Jurnal Pendidikan Anak Usia Dini, 4(1), 10. https://doi.org/10.31004/obsesi.v4i1.255

Wahjoedi, Adi, I. P. P., \& Damiati. (2017). Model Pengembangan Pendidikan Karakter Pada Anak Usia Dini Berbasis Outbound di Kota Singaraja. Seminar Nasional Riset Inovatif, 5, 931-940. https://eproceeding.undiksha.ac.id/index.php/senari/article/view/1068/793

Wahyuni, F. (2019). Pendidikan Anak Usia Dini ( PAUD ) Holistik Integratif. Qalamuna, 11(2), 61-72.

Wardani, D. N., Toenlioe, A. J. E., \& Wedi, A. (2018). Daya Tarik Pembelajaran Di Era 21 Dengan Blended Learning. Jurnal Kajian Teknologi Pendidikan (JKTP), 1(1), 13-18.

Wulandari, H., Supriyati, Y., \& Jalal, F. (2018). Evaluation of Holistic Integrative Program in Early Childhood Education and Development (PAUD HI). Int. J. of Multidisciplinary and Current Research, 6(June). https://doi.org/https://doi.org/10.14741/ijmcr/v.6.3.2

Yulianto, D., Lestainingrum, A., \& Utomo, H. budi. (2016). Analisis Pembelajaran Holistik Integratif Pada Anak Di Taman Kanak-Kanak Negeri Pembina Grogol Kabupaten Kediri. JPUD - Jurnal Pendidikan Usia Dini, 10(2), 277-294. https://doi.org/10.21009/jpud.102.05

Yuliati, Y., \& Saputra, D. S. (2020). Membangun Kemandirian Belajar Mahasiswa Melalui Blended Learning Di Masa Pandemi Covid-19. Jurnal Elementaria Edukasia, 3(1), 142 149. http://jurnal.unma.ac.id/index.php/jee/article/view/2218

Zahro, I. F., Atika, A. R., \& Westhisi, S. M. (2019). Strategi Pembelajaran Literasi Sains Untuk Anak Usia Dini. Jurnal Ilmiah Potensia, 4(2), 121-130. 